\title{
Ketamine Hydrochloride as a General Anesthetic for Domestic Fowl Chicks: Onset and Recovery from Anesthesia
}

\author{
Elsayed E. Elowni*, Ghada H. Abdelnabi, Mohamed F. Ahmad \\ Faculty of Veterinary Medicine, University of Khartoum, Shambat, Khartoum, Sudan \\ Email: *elsayedelowni@gmail.com
}

How to cite this paper: Elowni, E.E., Abdelnabi, G.H. and Ahmad, M.F. (2020) Ketamine Hydrochloride as a General Anesthetic for Domestic Fowl Chicks: Onset and Recovery from Anesthesia. Open Access Library Journal, 7: e6463.

https://doi.org/10.4236/oalib.1106463

Received: May 26, 2020

Accepted: June 13, 2020

Published: June 16, 2020

Copyright $\odot 2020$ by author(s) and Open Access Library Inc.

This work is licensed under the Creative Commons Attribution International License (CC BY 4.0).

http://creativecommons.org/licenses/by/4.0/

(c) (i) Open Access

\begin{abstract}
The domestic fowl, as a species, is considered a unique experimental model in immunological research where the humoral and cellular components of the immune response can be delineated by selective surgical bursectomy of newly hatched chicks combined with sublethal whole-body X-irradiation. Search for an effective, safe, and a short-acting general anesthetic for application in such young birds is, therefore, essential. Ketamine is a phencyclidine derivative with analgesic and anesthetic properties in both mammalian and avian species. Studies on its efficacy on young or naturally small birds, however, are apparently lacking. Our previous studies indicated that dose levels as high as $51 \mathrm{mg} / \mathrm{kg}$ and $37.2 \mathrm{mg} / \mathrm{kg}$ are not lethal to 2-day- and 6-day-old Hisex White domestic fowl chicks when given intramuscularly, respectively. Results of the present study show that the onset of ketamine anesthesia varied between 40 - 98 seconds in 2-day-old chicks of this breed depending upon dose level. The dose and response are inversely related $(y=-19.3 x+107.5)$ where " $y$ " is the time for onset of anesthesia in seconds and " $\mathrm{x}$ " is the dose as $\mathrm{mg} / \mathrm{bird}$. The time for recovery from anesthesia also varied (6.6 - $74.7 \mathrm{~min})$ depending upon dose level. The dose and response, however, are positively correlated $(y=20.92 x-21.15)$. Doses ranging between 43.77 to $47.74 \mathrm{mg} / \mathrm{kg}$ are considered optimum to produce anesthesia with onset in $74-77 \mathrm{sec}$ and recovery within $12-15 \mathrm{~min}$. It is concluded that Ketamine has the potential for application as a general anesthetic for domestic fowl chicks for bursectomy. Critical clinical tests are necessary to evaluate further the performance of this drug when administered to young chicks.
\end{abstract}

\section{Subject Areas \\ Veterinary Medicine}

\section{Keywords}

Ketamine Hydrochloride, Domestic Fowl, Chicks, Anesthesia 


\section{Introduction}

Ketamine is a phencyclidine derivative with analgesic and anesthetic properties in both mammalian and avian species. The drug is recommended as a suitable injectable general anesthetic in a wide range of avian species [1] [2] [3]. It has a wide margin of safety in most of these species [4]. According to Ludders and Matthews [5], the drug is suitable for chemical restraint for minor surgical and diagnostic procedures. Despite such wide application and reliability of the drug, studies on its efficacy on naturally small or young birds are apparently lacking.

The domestic fowl (Gallus gallus domesticus), as a species, is considered a unique experimental model for the study of immunological mechanisms in birds where the humoral and cellular components of these mechanisms can be delineated by selective abrogation of bursal or thymic functions. Several techniques [6] have been used to ablate both the bursa and bursa-derived migrating lymphocytes. These include hormonal injection in chick embryos, surgical extirpation of the developing bursa during embryonic life, in ovo intravenous injection of antibody specific for the IgM heavy chain or treatment with cyclophosphamide, colchicine or infectious bursal disease virus. Schusser et al. [7] developed a technique targeting genes in the chicken genome leading to loss of antibody production and a block in B-cell development. Surgical bursectomy at hatching, on the other hand, particularly when combined with sublethal X-irradiation, has been shown to have a profound suppressive effect on the subsequent ability of the chicken to form antibodies to several antigens [8] [9]. This surgical approach, however, requires an effective, safe and a short-acting anesthetic agent to enable surgical operation in such small birds. In an earlier study [10], we studied the quantal response of 2-day- and 6-day-old Hisex White domestic fowl chicks to ketamine hydrochloride anesthesia upon intramuscular injection. The results of these studies indicated that dose levels as high as $51 \mathrm{mg} / \mathrm{kg}$ and $37.2 \mathrm{mg} / \mathrm{kg}$ are not lethal to birds of the two age groups, respectively. The objective of the present study was to determine the time for onset of anesthesia (measured subjectively from the instant of drug injection until the bird fell permanently to its side) and the time for recovery from anesthesia (time taken between the onset of anesthesia and the time the bird reverted to a sitting position).

\section{Material and Methods}

Forty 2-day-old male Hisex White chicks, weighing 32.8 - $39.5 \mathrm{~g}$, average $36.2 \mathrm{~g}$, were randomly divided into 4 groups each comprising 10 birds. They received ketamine hydrochloride (ROTEXMEDICA GmbH, Trittau, Germany) intramuscular injections diluted in sterile physiological saline given at doses in a geometric progression at $0.5,1,2$ or $4 \mathrm{mg} / \mathrm{bird}(13.81,27.62,55.24$ or $110.5 \mathrm{mg} / \mathrm{kg}$ body weight; bwt.) using extra fine needles.

\section{Results and Discussion}

Figure 1 shows that the onset of anesthesia varied between 40 - 98 seconds in 
different groups of birds. The Dose and response are inversely related ( $\mathrm{y}=$ $-19.3 x+107.5)$ where " $y$ " is the time for onset of anesthesia in seconds and " $x$ " is the dose as $\mathrm{mg} / \mathrm{bird}$. Recovery from anesthesia, as judged by reversion of birds to a sitting position, also varied between groups (6.6 - $74.7 \mathrm{~min}$ ) depending upon dose level (Figure 2). The dose and response, however, are positively correlated $(y=20.92 x-21.15)$. According to Sinn [11], ketamine is effective as a general anesthetic in various species of birds at doses of $5-75 \mathrm{mg} / \mathrm{kg}$ bwt. In this regard, results of a previous study, in which we used Hisex White chicks, indicated that a dose as high as $51 \mathrm{mg} / \mathrm{kg}$ is not toxic to 2-day-old birds of this breed [10]. In the present study, using the formula $(y=20.92 x-21.15)$, an anesthesia targeted for $15 \mathrm{~min}$, as example, is expected to be produced by a dose of $47.74 \mathrm{mg} / \mathrm{kg}$ in 2-day-old chicks of average bwt $36.2 \mathrm{~g}$. In our experience [9], however, this period would exceed the actual time required for bursectomy in domestic fowl chicks. Thus, to reduce this recovery time from 15 to $12 \mathrm{~min}$ for instance, which is an advantage, a dose lower than $47.74 \mathrm{mg} / \mathrm{kg}$ (i.e. $43.77 \mathrm{mg} / \mathrm{kg}$ ) is required for birds to recover within this 12 -min time limit $(y=20.92 x-21.15)$. The time for onset of anesthesia in this case, however, would be increased to 77 seconds $(y=-19.3 \mathrm{x}+$ $107.5)$ as compared with 74 seconds when the higher dose $(47.74 \mathrm{mg} / \mathrm{kg})$ is used.

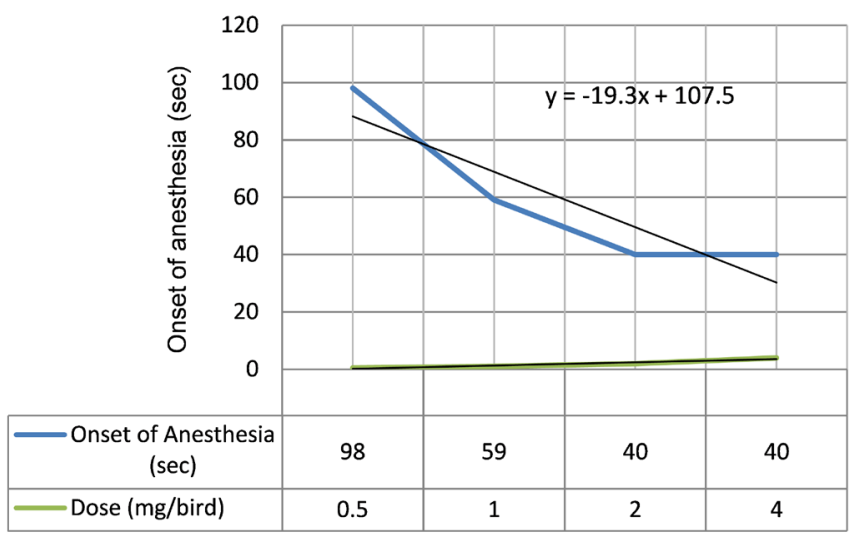

Figure 1. Onset ${ }^{*}$ of ketamine-induced anesthesia in 2-day-old Hisex White chicks (MS Excel). ${ }^{\star}$ Mean time; $\mathrm{n}=10$.

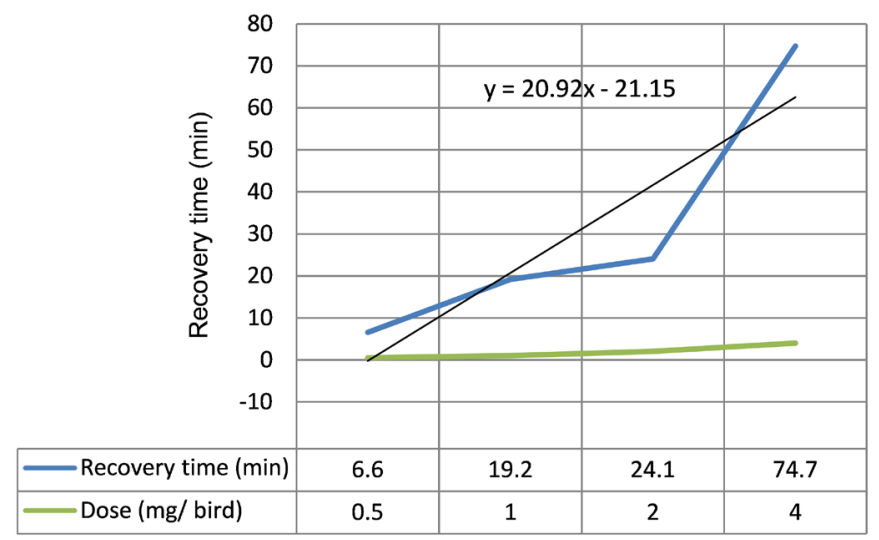

Figure 2. Recovery * from ketamine-induced anesthesia in 2-day-old Hisex White chicks (MS Excel). ${ }^{\star}$ Mean time; $\mathrm{n}=10$. 
Ketamine is recognized as a suitable injectable general anesthetic in a wide range of avian species with a wide margin of safety in most of these species [1] [2] [3] [4]. Several undesirable effects such as muscle rigidity, opisthotonus, violent and/or prolonged recoveries, however, have been attributed to its use in a number of these species [11] [12] [13]. The drug has, therefore, been recommended to be applied in combination with other injectable agents to reduce or eliminate such untoward effects [14] [15]. Applying the above formulae, the results indicate that doses at $43.77-47.74 \mathrm{mg} / \mathrm{kg}$ would produce anesthesia with onset within $74-77 \mathrm{sec}$, and recovery as early as $12-15 \mathrm{~min}$. It has been noticed, however, that the recovery was convulsive especially in the group treated with the extreme dose of $110.5 \mathrm{mg} / \mathrm{kg}$ and where the recovery was exceptionally protracted, lasting $74.7 \mathrm{~min}$ (Figure 2). In contrast, results we obtained from an earlier study [16] indicated that recovery from ketamine anesthesia was smooth in chicks of a different breed (Ros) of an age comparable to that of Hisex White when birds were treated with similar drug doses. Smooth recovery was also noticed in 40-day-old White Leghorn cockerels given ketamine hydrochloride i.m. injections at doses of 20, 30 or $60 \mathrm{mg} / \mathrm{kg}$ [17]. According to several authors [11] [13] [18], one of the greatest disadvantages of injectable anesthesia is the inter-species variability in the response to therapeutic doses as well as variability within species at the individual level. Whether the rough recovery from ketamine anesthesia reported in the present study in Hisex White is due to a breed difference remains to be verified.

\section{Conclusion}

Results of a previous study indicated that a dose as high as $51 \mathrm{mg} / \mathrm{kg}$ is not toxic to 2-day-old domestic fowl chicks upon i.m injection. The present findings show that doses ranging between 43.77 to $47.74 \mathrm{mg} / \mathrm{kg}$, as predicted mathematically, would produce anesthesia with onset within $74-77 \mathrm{sec}$, and a recovery within 12 - $15 \mathrm{~min}$. It is concluded that ketamine has the potential for application as a general anesthetic for domestic fowl chicks for bursectomy. Critical clinical tests are necessary to evaluate further the performance of the drug when administered to young chicks.

\section{Conflicts of Interest}

The authors declare no conflicts of interest regarding the publication of this paper.

\section{Acknowledgements}

The authors wish to thank Coral Company Ltd., Khartoum, for the supply of Hisex White chicks.

\section{References}

[1] Kittle, E.L. (1971) Ketamine HCL as an Anesthetic for Birds. Modern Veterinary Practice, 52, 40-41.

[2] Boever, W.J. and Wright, W. (1975) Use of Ketamine for Restraint and Anesthesia of Birds. Veterinary Medicinel Small Animal Clinician, 70, 86-88. 
[3] Flecknell, P.A. (2009) Anesthesia of Common Laboratory Species: Special Considerations in Laboratory Animal Anesthesia. Academic Press, San Diego, 181-273. https://doi.org/10.1016/B978-0-12-369376-1.00006-X

[4] Anon (2001) Veterinary Anesthetic and Analgesic Formulary. 3rd Edition, Version G, University of Colorado, Boulder, 1-24.

[5] Ludders, J.W. and Mathews, N.S. (2007) Birds. In: Tranquilli, W.J., Thurmon, J.C. and Green, K.A., Eds., Lumb and Jones Veterinary Anesthesia and Analgesia, 4th Edition, Wiley-Blackwell, Hoboken, 841-868.

[6] Elowni, E.E. (1985) Bursectomy in Chickens: A Review. Sudan Journal of Veterinary Science and Animal Husbandry, 25, 29-38.

[7] Schussera, B., Collarinia, E.J., Yia, H., Izquierdoa, S.M., Feslera, J., Pedersena, D., et al. (2013) Immunoglobulin Knockout Chickens via Efficient Homologous Recombination in Primordial Germ Cells. Proceedings of the National Academy of Sciences of the United States, 110, 20170-20175.

https://doi.org/10.1073/pnas.1317106110

[8] Cooper, M.D., Raymond, D.A., Peterson, M.A.S. and Good, R.A. (1966) The Functions of the Thymus System and the Bursa System in the Chicken. Journal of Experimental Medicine, 123, 75-102. https://doi.org/10.1084/jem.123.1.75

[9] Elowni, E.E. and Hopkins, C.A. (1981) Raillietina cesticillus. Rejection by Bursa-Deficient Chickens. Research in Veterinary Science, 31, 373-376. https://doi.org/10.1016/S0034-5288(18)32474-3

[10] Elowni, E.E., Ahmed, M.F., Abdelnabi, G.H. and Badawi, R.M. (2019) Ketamine Hydrochloride as a General Anesthetic for Domestic Fowl Chicks: Quantal Response. Sudan Journal of Science and Technology, 20, 22-26.

[11] Sinn, L.C. (1994) Anesthesiology. In: Avian Medicine: Principles and Application, Wingers Publishing, Lake Worth, Chapter 39.

[12] Laweighton, M.P.C. (1984) Avian Anesthesia. Veterinary Record, 115, 71. https://doi.org/10.1136/vr.115.3.71

[13] Paul-Murphy, J. and Fialkowski, J. (2001) Injectable Anesthesia and Analgesia of Birds. In: Gleed, R.D. and Ludders, J.W., Eds., Recent Advances in Veterinary Anesthesia and Analgesia: Companion Animals, International Veterinary Information Service, New York, 1-15.

[14] Maiti, S.K., Tiwary, R., Vasan, P. and Dutta, A. (2006) Xylazine, Diazepam and Midazolam Premedicated Ketamine Anesthesia in White Leghorn Cockerels for Typhlectomy. Journal of the South African Veterinary Association, 77, 12-18. https://doi.org/10.4102/jsava.v77i1.333

[15] Durrani, U.F. (2014) Comparative Study on Sedative and Anesthetic Effects of Xylazine, Ketamine and Xylazine-Ketamine Combination in Quails (Coturnix coturnix). IOSR Journal f Agriculture and Veterinary Science, 7, 29-33. https://doi.org/10.9790/2380-07632933

[16] Elowni, E.E., Sanhouri, A.A., Dafalla, R.A., Makky, E.A.M., Aldood, M.E. and Yassin, M.A. (2019) Evaluation of Ketamine as a General Anesthetic for Domestic Fowl Chicks. Sudan Journal of Science and Technology, 20, 111-115.

[17] Elowni, E.E., Sanhouri, A.A., Makky, E.A.M., Dafalla, R.A., Aldood, M.E. and Yassin, M.A. (2019) Performance of Ketamine as a General Anesthetic for Domestic Fowl. Sudan Journal of Science and Technology, 20, 64-68.

[18] Miller, W. and Buttrick, M. (1999) Current Anesthesia Recommendations for Companion Birds. Iowa State University Veterinarian, 61, 67-75. 